\section{Painful Enlargement of Left Subtrapezoid Lymph Nodes in Graves's Disease}

\author{
J. E. MAHAUX, J. CHAMLA-SOUMENKOFF, \\ R. DELCOURT, S. LEVIN
}

British Medical fournal, 1971, 1, 384

It has been known for a long time that in Graves's disease hyperplasia of the cervical nodes which drain thyroid lymph may occur. "Enlargement of the lymphatic glands, moderate in degree and not progressive, may develop rapidly and slowly subside" (Gowers, 1888). In particular the left subtrapezoid or pretrapezoid chain appears to be involved (Gueneau de Mussy, 1881). As this sign has been almost forgotten in recent years and may be useful in diagnosis where other signs and symptoms are atypical, a further case is presented below.

\section{Case Record}

After a prolonged period of overexertion lasting some six months a 36-year-old man, previously fit, had an attack of violent palpitation and trembling. An intense muscular weakness made it impossible for him even to get dressed by himself. His appetite disappeared until there was nearly total anorexia accompanied by thirst. His weight fell from 77 to $67 \mathrm{~kg}$ over a period of two months. He complained of "a stiff neck" on the left side.

On examination of the left trapezoid region numerous small lymph nodes were palpated, and these were painful and tender (Fig. 1A). There were also a few tender lymph nodes on the right side. The thyroid was moderately enlarged.

Investigations revealed B.M.R. $+51 \%$; pulse $108 / \mathrm{min}$; blood P.B.I. $>20 \mu \mathrm{g} / 100 \mathrm{ml}$; serum thyroxine-iodine $>20 \mu \mathrm{g} / 100 \mathrm{ml}$; T-3 uptake (resin) $66.1 \%$; blood cholesterol $100 \mathrm{mg} / 100 \mathrm{ml}$; immunoglobulins: IgA $128 \mathrm{mg}$, IgM $75 \mathrm{mg}$, IgG $680 \mathrm{mg}$ (total $883 \mathrm{mg}$ ) per $100 \mathrm{ml}$.

He was treated with carbimazole $(30 \mathrm{mg} /$ day), which brought about a progressive clinical improvement (Fig. 1B). After three weeks investigations showed B.M.R.+18\%; P.B.I. $11.2 \mu \mathrm{g} / 100 \mathrm{ml}$; serum thyroxine-iodine $8.2 \mu \mathrm{g} / 100 \mathrm{ml}$; blood cholesterol $154 \mathrm{mg} / 100 \mathrm{ml}$; IgA $172 \mathrm{mg}$, IgM $130 \mathrm{mg}$, IgG $1,100 \mathrm{mg}$ (total $1,400 \mathrm{mg}$ ) per $100 \mathrm{ml}$. The tenderness of the lymph nodes diminished progressively, the anterior part of the network becoming impalpable and only the posterior part remaining clearly perceptible. The spontaneous pain resolved.

After eight weeks the patient appeared to be euthyroid. B.M.R. $+9 \%$; blood P.B.I. $6.5 \mu \mathrm{g} / 100 \mathrm{ml}$; blood cholesterol $220 \mathrm{mg} / 100 \mathrm{ml} ; \mathrm{IgA} 172 \mathrm{mg} / 100 \mathrm{ml}, \operatorname{IgM} 123 \mathrm{mg} / 100 \mathrm{ml}, 1 \mathrm{gG}$ $1,120 \mathrm{mg} / 100 \mathrm{ml}$ (total $1,415 \mathrm{mg} / 100 \mathrm{ml}$ ).

The posterior group of lymph nodes on the left side remained palpable and tender. A chain of three tender lymph nodes could also be detected at the base of the neck (Fig. 1C). The other lymph nodes were no longer palpable.

Subsequently intrathyroidal injection of a microcolloid of Au-198 has made possible the visualization by the scintillation camera of

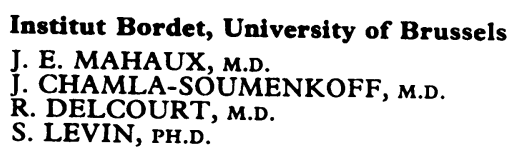

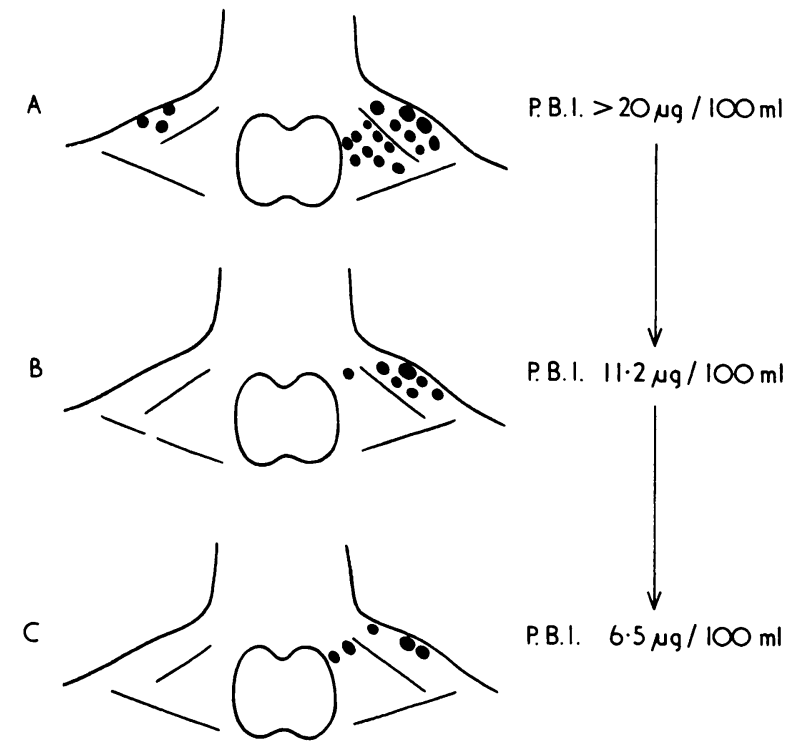

FIG. 1-Diagram of site and response to treatment of enlarged tender cervical lymph nodes in a severe case of Graves's disease (A) before treatment (P.B.I. $>20 \mu \mathrm{g} / 100 \mathrm{ml}$ ), (B) after three weeks of carbimazol (P.B.I. $11 \cdot 2 \mu \mathrm{g} / 100 \mathrm{ml}$ ), and (C) after eight weeks (P.B.I. $6.5 \mu \mathrm{g} / 100 \mathrm{ml}$ ).

the rapid flow of the radioisotope to the juxtathyroid lymph nodes and to substernal lymph nodes (Chamla-Soumenkoff et al., 1971).

\section{Comment}

Daniel et al. (1966) showed that the cervical lymphatic system is a pathway of major importance for the outflow of iodoproteins from the thyroid gland. The concentration of the radioactive iodoprotein fractions is very high in thyroid lymph, less so in cervical lymph, and very low in peripheral blood. The decrease in concentration in the lymphatic vessels has been attributed to a dilution by lymph from non-thyroid tissue in the head and neck (Daniel et al., 1966, 1967).

The development in certain severe hyperthyroid conditions of a whole network of subtrapezoid lymph nodes which are normally not apparent and its partial regression during the treatment of the hyperthyroidism arouse speculation about the presence in lymphoid tissue of an active mechanism of deiodination and proteolysis which would protect the organism from a dangerous increase of the thyroglobulin levels.

The relationship between the thyroid and the organism does not limit itself to an intravascular secretion of variable quantities of thyroxine and triiodothyronine in response to a stimulation produced by a neurohypophysial servomechanism. The thyroid gland also releases thyroglobulin, a hormonal macromolecule with high iodine concentration, the penetration of which into the general circulation appears to be controlled by a ganglionic system of homoeostasis.

\section{References}

Chamla-Soumenkoff, J., Frühling, J., and Mahaux, J. E., (1971). Annales d'Endocrinologie, In Press.

Daniel, P. M., Plaskett, L. G., and Pratt, O. E. (1966). Biochemical fournal, 100,622 .

Daniel, P. M., Pratt, O. E., Roitt, I. M., and Torrigiani, G. (1967). Immunology 12, 489.

Gowers, W. R. (1888). A Manual of Diseases of the Nervous System, vol. 2, p. 807. London, Churchill.

Gueneau de Mussy, N. (1881). Bulletin et Mémoires de la Société de Thérapeutique, 8,218 . 